\title{
Biblical Rhetoric of Separatism and Universalism and Its Intolerant Consequences
}

\author{
James W. Watts \\ Department of Religion, Syracuse University, Syracuse, NY 13244, USA; jwwatts@syr.edu
}

Received: 28 February 2020; Accepted: 8 April 2020; Published: 9 April 2020

\begin{abstract}
The long history of the Jewish and Christian use of separatist rhetoric and universal ideals reveals their negative consequences. The Hebrew Bible's rhetoric about Israel as a people separated from the Egyptians and Canaanites is connected to Israel's purity practices in Leviticus 18 and 20. Later communities wielding greater political power, however, employed this same anti-Canaanite pollution rhetoric in their efforts to colonize many different parts of the world. Separatist rhetoric was used to protect small Jewish communities in the early Second Temple period. The Christian New Testament rejected many of these purity practices in order to makes its mission more inclusive and universal. However, its denigration of concerns for purification as typically "Jewish" fueled intolerance of Jews in the form of Christian anti-Semitism. The violent history of both separatist and universalist rhetoric provides a cautionary tale about the consequences of using cultural and religious comparisons for community formation.
\end{abstract}

Keywords: particularism; universalism; intolerance; purity; Leviticus; colonialism; anti-Semitism

\section{Introduction}

Most of the articles in this special issue on religious conflicts and coexistence focus on contemporary religious communities or relatively recent history. That makes sense, because the great advantage of studying contemporary religions and cultures is that they are well documented, and we can check our interpretations by asking participants about them, perhaps even by becoming participants ourselves. By contrast, students of ancient history suffer the disadvantage of interpreting fragmentary remains that leave large gaps in our understanding. We often do not know why people wrote what they did and how it actually affected their religious lives and institutions. Studies of the distant past, however, have one big advantage over studies of contemporary cultures: history allows us to trace the effects of religious rhetoric and practices over centuries and millennia to reveal not only their influence, but also their unintended consequences.

My focus here is on interactions between two religions that span history from their ancient origins to the modern day. Just like new religious movements today, many ancient religions began with particular reactions to other religious traditions around them. The specific reactions I will describe here, separatism (or particularism) and universalism, have both generated intolerant violence, often within the same religious tradition. Though religious universalists tend to depict separatism as the opposite of their universalism to distinguish themselves from other religious groups, that claim has obscured the use of separatism by their own traditions, as well as the universalistic tendencies of the religious traditions that they oppose.

This history has been told many times before, and in much more detail than I can provide here. The role of separatist and universalist ideals in people's religious identities are inevitably more complicated than any broad survey can show, especially one as short as this article. However, I believe that this history, that juxtaposes some of the deleterious effects of both separatism and universalism, needs to be repeated to show how moral judgments on others' religious practices can generate even 
worse abuses. Separatism and universalism have been frequently cited by one religious tradition, Christianity, to distinguish itself from another, Judaism, but the history surveyed here shows that this distinction and the values attributed to it do not hold. Despite their apparent opposition, both separatist and universalist elements in biblical texts have frequently been used by the same religious groups to attack and oppress others. I offer this review as a cautionary tale of how opposite religious ideals embraced at the origins of two traditions can go unexpectedly and badly wrong.

First, a comment about terminology. The meaning of the terms, universalism and particularism, has been widely debated, as has their appropriate application (e.g., Billet 2007; Donnelly 2007). This essay uses them as they have traditionally appeared in Judaism and Christianity and in the polemics between them, and only gestures to their wider application. I use "separatism" more often than "particularism" because biblical mandates (see below) call on Israel literally "to separate" itself from other nations. Religious universalism - the claim that every human faces, or at least should be offered, the same religious choices-has been a staple of Christian self-descriptions since ancient times (Ruether 1974, pp. 34-36, 141, 151; Schott 2013). This use of "universalism" to describe religious thought resembles its use in the social sciences to distinguish between universalistic and particularistic cultures (de Blasio et al. 2019). On the other hand, eschatological universalism, the belief that everybody will be saved, is not under discussion in this article.

\section{Biblical Separatist Rhetoric}

Around two-thousand-five-hundred years ago, Judah was a small kingdom, and then an imperial province, threatened by the territorial ambitions of neighboring rulers and of distant empires. The first five books of the Bible, called the Torah or Pentateuch, and later the whole Hebrew Bible, also called the Tanak or Old Testament, were among the tools used by Judah's priestly class to weld together ethnic identity and national aspirations into a religious identity as Jews (Nasuti 1986, p. 12; Sanders 2009, pp. 157-71; Collins 2017, pp. 15,44-61). The Bible does this by narrating Israel's origins in ancestors, from Abraham through Moses, who migrated to this territory one thousand years earlier. It also establishes the people's identity through the covenant that they made with their god, YHWH, at Mount Sinai.

The Hebrew Bible has wielded enormous influence in subsequent forms of Judaism, Christianity, and Islam, and over the cultures worldwide in which these religions have spread. Its famous contributions have included ethical monotheism and scripture-focused piety, among other things. The Bible has also been criticized for reinforcing cultural patriarchy and for justifying the institutions of chattel slavery, among other things. The overall influence of a religious tradition or its scripture is too broad and diffuse to allow for a convincing evaluation (though some have tried; for opposite examples, see (Stark 2004; Avalos 2013)). Instead, I will focus here on one strand of the biblical tradition, rooted in just a few verses, that has promoted intolerance in the name of religious separatism and also provoked a critical response in the form of religious universalism.

Among the stipulations of Israel's covenant are commandments to behave in certain distinctive ways to mark their identity as God's people, the people of Israel. These practices are rooted in the Torah's demand that the Israelites maintain their purity in order to distinguish themselves from other peoples. The association of purity with religious identity is made especially clear by a sequence of three passages in Leviticus 18 and 20 (see Table 1).

These commands appear in the story of the revelation of the Torah at Mount Sinai. They are set in time between the Israelites' exodus out of Egypt and their settlement of the land of Canaan, the land that God has promised to give them. These verses call on the Israelites to obey the laws of the covenant in order to distinguish themselves from the Egyptians and from the Canaanites (18:3-4). The failure to follow these rules, which in the immediate context concern mostly sexual behavior, leads to the pollution of the people and of the land. Here, the biblical text provides an explicit justification for displacing the Canaanites from their land: they have polluted it by behaving in ways prohibited by YHWH's laws (18:24-28; Frevel 2019). 
Table 1. Rhetoric of Separation in Leviticus.

\begin{tabular}{|c|c|}
\hline Leviticus 18:3-4 & $\begin{array}{l}\text { What is done in the land of Egypt where you lived-you must not do, and what is done in } \\
\text { the land of Canaan into which I am bringing you-you must not do, and their } \\
\text { mandates-you must not obey. But my judgments you must do, and my mandates you } \\
\text { must observe to obey them-I am YHWH your God. }\end{array}$ \\
\hline $\begin{array}{l}\text { Leviticus } \\
18: 24-28\end{array}$ & $\begin{array}{l}\text { Do not pollute yourselves with all of these things, because the nations that I am expelling } \\
\text { before you are polluted with all of these so that the land is polluted. I will hold it liable for } \\
\text { it, and the land will vomit out its inhabitations. You especially must observe my mandates } \\
\text { and my judgments and not do any of these disgusting things,... Because all of these } \\
\text { disgusting things were done by the people of the land who were before you, and the land } \\
\text { was polluted. So that the land does not vomit you out when you pollute it, like it vomited } \\
\text { out the nations before you. }\end{array}$ \\
\hline $\begin{array}{l}\text { Leviticus } \\
20: 24-26\end{array}$ & $\begin{array}{l}\text { I said to you: you will possess their ground. I will give it to you to possess it, a land } \\
\text { flowing milk and honey. I am YHWH your God who separated you from the peoples. } \\
\text { You must separate pure quadrupeds from the polluted, and polluted flyers from the pure, } \\
\text { so you do not nauseate yourselves with quadrupeds, flyers and everything with which the } \\
\text { ground crawls that I have separated as polluted for you. You are holy to me because I, } \\
\text { YHWH, am holy. I have separated you from the peoples to be mine. }{ }^{1}\end{array}$ \\
\hline
\end{tabular}

These texts draw an explicit analogy between the Israelites' daily separation of pure meat from polluted and God's separation of the people of Israel as belonging to YHWH. The act of separation (Hebrew: badal) also typified God's activity in creating the world in Genesis 1. Thus, Leviticus 20 calls on its listeners and readers to distinguish among food animals to show their status as the people distinguished by God and in imitation of God's acts in creating the world, all activities defined as "separation" (Milgrom 2000, pp. 1761-62). This rhetoric aims to create communal identity by drawing explicit contrasts with other groups (Olyan 2000, pp. 63-102). These other people are labeled by the names of Israel's ancient enemies, Egypt and Canaan (18:3-4), but the text of Leviticus already extends that identification to peoples ('ammim) generally, in all places and all times (20:24-26).

Such rhetoric is not limited to Leviticus. The intention to dispossess the Canaanites of their lands appears as early as the promises to the ancestors in Genesis $(15: 18-21 ; 17: 8)$ and motivates the story of the exodus from Egypt (Exodus 3:8; 6:4, 8) and the conquest of the land (Numbers 33:51-53; Deuteronomy 7:1-3; Joshua 11:23). The divine command to separate themselves from the Canaanites motivates the execution of captives during these wars (Numbers 31:14-18; 33:55; Deuteronomy 7:16; 20:12-13, 16-18; 25:17-19; Joshua 6:17-21; 8:18-29; 10:22-12:24; 1 Samuel 15) or their reduction to forced labor (Deuteronomy 20:10-11; Joshua 9:26-27).

\section{Uses of Biblical Separatist Rhetoric in the Americas}

The influence of the Bible's rhetoric of separation from the Canaanites and other peoples has been especially evident in the cultures of the American continents over the last five centuries (Warrior 1989; Hidalgo 2018, pp. 63-67). During the Spanish and Portuguese conquests of the Americas, the rights of the native peoples were hotly debated on both sides of the Atlantic (Prior 1997, pp. 48-70; Newcomb 2008, pp. 43-50; Staubli 2011, p. 375). In 1493, Pope Alexander VI issued a papal bull, “Inter Caetera," that granted non-Christians' lands in the Americas to the Spaniards so they could convert the inhabitants to Christianity, a precedent called the Doctrine of Discovery. Defenders of the Spanish and Portuguese conquests used biblical narratives and laws to justify them. Fray Toribio de Motolinia blamed the depopulation of Indian communities on diseases and plagues in punishment for their sins (Prior 1997, p. 61). Juan Ginés de Sepúlveda in 1545 cited Leviticus and Deuteronomy to justify the conquest of the Americas because of the Indians' crimes and unbelief (Prior 1997, pp. 56, 68).

1 English translations by the author. 
Pedro de Santander in 1557 urged King Philip II of Spain to treat Florida like Canaan: "This is the Land of Promise, possessed by idolaters, the Amorite, Amelekite, Moabite, Canaanite. This is the land promised by the Eternal Father to the Faithful, since we are commanded by God in the Holy Scriptures to take it from them, being idolators, and, by reason of their idolatry and sin, to put them all to the knife, leaving no living thing save maidens and children, their cities robbed and sacked, their walls and houses leveled to the earth" (de Pital and Salvá 1855; Parkman 1996, p. 18; Newcomb 2008, p. 50).

The depredations of the conquistadores led to impassioned defenses of Indian rights by some Spaniards who witnessed them. Most notably, Bartolomé de Las Casas wrote a critical history of the conquest and defended the Indians before a royal commission in 1550. Other defenders of the Indians used biblical language to identify themselves as "in Babylon," i.e., in exile, and "in Ninevah" like the prophet Jonah, in preaching to the Spanish conquerors. They compared the Indians' fate to that of the Israelites in Egypt (Prior 1997, pp. 59-62). In 1557, Francisco de Vitoria wrote an influential treatise that denied the application of the Doctrine of Discovery to the Americas, since the land was already occupied: "the barbarians were the true owners, both from the public and from the private standpoint" (Newcomb 2008, p. 163). Wilkens (2014) has claimed that Vitoria's point of view dominated most legal interactions with Native Americans in the following centuries, which therefore took the form of treaties between recognized nations. However, people continued to claim that the conquest of inferior and immoral native peoples established rights to land and dominion in the Americas.

The biblical model of the conquest of Canaan motivated many English settlers of North America (Staubli 2011, pp. 376-77). In 1583, Sir George Peckham justified accepting a large grant of lands in New England by referring to God's grant of Canaan to Israel (Cave 1988, p. 282). Seventeenth-century preachers compared the Native Americans to the Canaanites and also to the builders of the Tower of Babel (Genesis 11) and to the descendants of Ham suffering Canaan's curse (Genesis 9:25; this verse was also employed to justify the African slave trade, but that is another story; see Haynes 2002; Goldenberg 2009). They argued that the Indians' idolatry condemned them to death under biblical law (Deuteronomy 17:2-7; Cave 1988, pp. 183-86). In Virginia, warfare with Native Americans was interpreted by Samuel Purchas through the language of Leviticus, as Paul Stevens has pointed out: "The Algonquian uprising of 1622, led by Pocahontas's uncle, Opecancanough, is read by Purchas through the mediating glass of Leviticus 18, and the Indian rebellion is represented as sexual transgression: 'When Virginia was violently ravished by her owne ruder Natives, yea her virgin cheekes dyed with the bloud of three colonies ... Temperance could not temper her selfe, yea the stupid Earth seems distempered with such bloudy potions and cries that shee is ready to spue out her inhabitants.'" (Stevens 1993, p. 455).

As was the case earlier among Spaniards, many sixteenth- and seventeenth-century English voices denied that Europeans had any divine grant to American lands (Cave 1988, pp. 280-81, 286-87, 289-90). The Puritans also did not think that Christians should dispossess Native Americans, but they argued that God had already emptied the land of eastern Massachusetts by plague before they arrived (Cave 1988, p. 290). Nevertheless, the belief in the providential right to take Indian land remained popular among English colonists, to the extent that Roger Williams was expelled from Massachusetts over his disagreement about this and other matters. In 1689, the influential minister, Cotton Mather, charged the colonies' soldiers to think of themselves as Israel in the wilderness battling Amalek: "pure Israel was obliged to 'cast out [the Indians] as dirt in the streets', and eliminate and exterminate them" (Prior 1997, p. 263).

These ideas continue to influence American politics and legal decisions. In 1823, the U.S. Supreme Court in Johnson v. McIntosh revived the Doctrine of Discovery as an element in United States law. This decision recognized that Indians originally occupied and possessed American lands but argued that property rights now depend upon the precedents established by European nations' right of conquest (Newcomb 2008, pp. 73-104; Wilkens 2014). This precedent echoes the biblical conquest story and continues to influence legal decisions about Native American land claims in the twentieth and twenty-first centuries. 


\section{Uses of Biblical Separatist Rhetoric Elsewhere}

Such biblical rhetoric was used earlier and frequently in Europe to justify missionary expeditions and military conquests. Christian missionaries in the early Middle Ages destroyed altars and sacred trees in imitation of the biblical prophet, Elijah (Staubli 2011, p. 374). Europe's medieval crusades to conquer "the holy land" were justified by accusations that Muslims polluted sacred sites (Cole 1993; Angenendt 2009). Monastic crusaders like the Knight Templers were inspired by hearing readings from Joshua and 1 Maccabees (Prior 1997, pp. 35-36).

In the sixteenth century, Protestant Reformers like Martin Luther depicted themselves as "purifying" churches of "Canaanite" pollution introduced by the Roman Catholic Church (Staubli 2011, p. 374; Elliott 2012, p. 194). John Calvin observed that the law in Leviticus 20:26 "has the rationale of maintaining a separation of God's people from the nations and their pollutions" (Elliott 2012, p. 212), a view echoed in the twentieth century by Northern Irish Protestants in their political struggles to stay separate from Catholic Ireland (Stevens 1993, p. 442). In the seventeenth century, the English poet, John Milton, denounced Catholic bishops as "the Canaanites and Philistines to this Kingdom" and castigated Irish rebels as sexually polluted, while Oliver Cromwell, who dethroned the British monarchs, claimed for himself the zeal of Phineas (Numbers 25:6-15) in keeping Israel clean (Stevens 1993, pp. 455-57).

In the nineteenth and twentieth centuries, South African Boers compared their eviction from Cape Town to the Exodus and used Deuteronomy, Ezra and Nehemiah to justify the separation of the races in the system of apartheid (Prior 1997, pp. 71-105; Staubli 2011, p. 378). Arab legends identified the Berbers negatively with the Canaanites (Staubli 2011, p. 378), though the rise of the modern state of Israel has led many Muslims to celebrate the Canaanites as predecessors of the Palestinians, both of whom suffer from Israelite/Israeli conquest (Staubli 2011, p. 379). Jewish Zionists initially preferred to use the stories of Israel's heroes in Joshua and the Maccabees rather than biblical law for their cause, but that has changed with the increasing influence in Israel of Orthodox Zionists in the later twentieth-century (Prior 1997, pp. 106-69). The biblical condemnation of the Canaanites continues to echo in the twenty-first-century rhetoric of Israeli settlers and of Christian Zionists, who cite the biblical conquest story (Richardson and Pihlaja 2018). Apart from Middle Eastern politics, it also continues to be cited in condemnations of atheism and non-hetero-normative sexual identities (e.g., in the 2005 papal encyclical, Deus caritas est, s. 31, quoted by (Elliott 2012, p. 212)).

\section{Separatism and Universalism in Ancient Judaism}

The origins of this rhetoric of ethnic and religious separation are best explained by the historical context of Judea in the fifth to fourth centuries B.C.E. when the Torah first began to be ritualized as a scripture (Collins 2017, pp. 44-61; Watts 2017, pp. 13-17). Judea was then a small province in the Persian Empire trying to defend its boundaries and interests against neighboring rivals. Judeans also struggled to gain unity over internal divisions. Local "people of the land" ('am ha'arets) were poor in contrast to the wealthier Judean diaspora in Egypt and Babylon. Some members of this diaspora returned to Judea and installed themselves as a ruling class in Jerusalem. They were represented most prominently in the fifth century by the prince, Zerubabbel, and the high priest, Joshua ben Yehozadak (Ezra 3:2), and in the fourth century by the priest and scribe, Ezra, and the Persian governor, Nehemiah (Ezra 7:1-6; Nehemiah 2:1-20). The population of the province of Judea also included immigrants (gerim) who, unlike native Judeans, could not claim ancestral ties to Israel. Jerusalem's status as the religious center of the cult of YHWH, the god of Israel, had to compete with rival claims by Samarians to YHWH worship on Mount Gerizim, to the north.

Judea's religious and secular leaders responded to the internal and external threats to the community's cohesion by evoking the Torah's rhetoric of identification with ancient Israel and of separation from other peoples. They developed it further, castigating foreigners as inherently polluted (Nehemiah 13:9, 28-30) and intermarriage as polluting the holy people of God (Ezra 9:10-11). This is a common strategy adopted by many small minority groups for community preservation. Though later 
Jews have not usually been as strict as Ezra and Nehemiah, the strategy of tying Jewish identity to venerating the Torah's laws, especially a distinctive diet, purification rituals and male circumcision, did help to preserve Jewish identity through millennia of minority status under Christian and Muslim rulers.

The Hebrew Bible, however, does not consistently advocate separation from foreigners. It also contains universalistic ideals, starting with creation and flood stories that show the ancestors of all humans receiving divine commands and blessings (Genesis 1:28; 9:1-7). Legal texts in the Torah emphasize the safety and rights of immigrants (gerim) living in Israel (Leviticus 19:33-34; Deuteronomy 10:18-19). Some prophets and psalms hope for all nations to worship God together in Jerusalem (Isaiah 66:18-24; Zechariah 14:16-21; Psalm 96). The books of Ruth and Daniel affirm the ability of non-Israelites to recognize and worship the one, true God.

Universalistic ideas continued to appear in the Jewish literature of the Second Temple period (515 B.C.E. to 70 C.E.). Malka Simkovich reviewed this material and concluded that "many Jews embraced universalist ideas, particularly during the last two centuries of the Second Temple era" (Simkovich 2017, p. 141). Later rabbinic literature of the first six centuries C.E. both reproduced the biblical bias against the Canaanites and also voiced universalistic impulses. For example, the Talmud reports that God prohibited the angels from celebrating the victory over Egypt at the Reed Sea (Exodus 14-15) out of sorrow over all the Egyptian dead (b. Megillah 10b; b. Sanhedrin 39b; Niditch 1993, pp. 150-51).

\section{Intolerant Christian Universalism}

Christian theology picked up these universalistic elements in the Jewish tradition and claimed them for itself. Various New Testament texts embrace the prophets' universalistic proclamations. The Gospels show Jesus quoting the commands to love neighbors and immigrants from Leviticus 19:18, 34, and extending that love even to enemies (Matthew 5:44). Christians are directed to preach the Gospel message "to all nations" (Matthew 28:19; Romans 1:16).

In order to implement this universal mission, the apostle Paul rejected practices like dietary rules and circumcision (1 Corinthians 10:23-33; Galatians 5:2) that had come to define Jewish identity as a separate people. Many New Testament texts characterize concern for food purity as a "Jewish" concern (Mark 7:3; Acts 10:28) in order to highlight and distinguish Christian universalism. Universalism became a self-described marker for distinguishing Christians from Jews. Christians identified separatist particularism as a defining fault of Judaism. Worries about "judaizing" tendencies among fellow Christians then continued to be voiced throughout subsequent history (Chrysostom 2010; Murphy 2007; Mattox 2008).

The Christian scriptures of Old and New Testaments thus canonized the identity politics of early Christians by describing the separatist practices from the Pentateuch as "Jewish" and rejecting them in favor of Christian universalism in the New Testament (Ruether 1974, pp. 226-34). This formula obscured the universalistic tendencies in ancient Judaism (Simkovich 2017), as well as the fact that the New Testament actually preserves a variety of views about purity, and especially the diet rules (Acts 15). Jon Levenson summarized the situation in the different biblical canons this way: "The material in the Hebrew Bible which touches on non-Israelite religion, like the material in the New Testament which touches on Judaism, is born in the white heat of polemic. In both cases, the sarcastic, reductionistic literature of polemic has come to be regarded as sacred Scripture" (Levenson 1985, pp. 254-55).

After Christianity received Roman imperial approval and then sponsorship in the fourth century, many Christian theologians fused the universal mission of the church with the empire's political universalism that celebrated the dominant culture and relegated all others to barbarism. Even before the rise of Christianity, Greco-Roman critics had labeled Jews as misanthropic because of their social separation from other peoples to avoid pollution (Schäfer 1997, pp. 21-22, 67). That charge continued to echo in Christian polemics against Jews, though often overshadowed by theological complaints about Jewish legalism and a failure to recognize the true Christ (for a historical survey of anti-Semitism, see Levy and Lindemann 2010). The Christian Roman Empire restricted Jewish legal and civil rights. 
The laws of Justinian (fifth century C.E.) banned the Mishnah and insisted that Jews should not be allowed to read the Bible in Hebrew (Ben-Sasson 1976, p. 359). Rosemary Radford Ruether reviewed the results: "Christianity ... took the universalism of the messianic hope and fused it with the ideological universalism of the ecumenical empire. ... One God, one faith, and one Church for all mankind invalidated the rights of other people to exist in other ways before God.... Historically, from this time on, the missionary and the conquistador went hand in hand" (Ruether 1974, pp. 141-43, 233-34).

Roman precedent and law, as codified by Christians, shaped the treatment of Jews by later churches and nations. In 1215, the Fourth Lateran Council proclaimed the supremacy of the Catholic Church over all Christian realms and, simultaneously, the universal marginalization of Jews. It required, among other things, that Jews wear distinctive badges to identify their outsider status (Carroll 2001, pp. 282-83). Later Christian prejudices about Jews emphasized economic conspiracy theories and secret rituals (such as the blood libel; Levy and Lindemann 2010, pp. 74-75) that fed on the stereotype of Jewish separatism. The Hebrew Bible's pollution rhetoric could also be turned into anti-Semitic rhetoric: for example, Catholics in the Counter-Reformation quoted the description of Israel's pollutions in Ezekiel to attack Jews (Staubli 2011, p. 375). These precedents influenced later European states, even through Jewish emancipation in the nineteenth century. In America, too, many Christians regarded a Jew as "the quintessential alien" (Dinnerstein 1994, p. 245). The twentieth-century revival of virulent anti-Semitic prejudices led to the Holocaust, the Nazi's "final solution of the Jewish problem".

Thus, the criticism of Jewish separatism as intolerant of other peoples led to a Christian universalism that has frequently demonized Jews and led to their violent persecution. Nevertheless, Christian universalism has often proven very attractive as the religion spread to new cultures. R. S. Sugirtharajah observed that many people in India and elsewhere in Asia responded positively to the New Testament, but found the Hebrew Bible perplexing and off-putting. As a result, missionaries had difficultly preaching from Old Testament texts (Sugirtharajah 2005, pp. 145-46, 163). Some missionaries adopted evolutionary models that identified Israelite and post-exilic Jewish religions with stages of religions in India, all leading to the ultimate Christian revelation (Sugirtharajah 2005, pp. 151-53). Some colonized peoples, however, embraced the Hebrew Bible's purity rules and conquest story as a means to criticize their colonizers based on their own scriptures. In nineteenth-century South India, for example, A. N. Suttampillai founded the Hindu Christian Church and, quoting Leviticus 18, "warned the British that if they did not reform their ways, they would be ousted, as had once happened to the nations of Palestine: 'Reform at once (Eph. 5.1-12). "That the land spue not you out also, as is spued out the nations that" were once in Palestine (Lev. 18.28)'" (Sugirtharajah 2005, p. 185, quoting Suttampillai 1890, p. 30).

\section{The Ambiguous Heritage of Separatist and Universal Rhetoric}

The effects of these conflicts between and within religious communities have not been confined to these communities. Christian ideas, often from the Bible, set the stage for the development of Western political theories in the sixteenth and seventeenth centuries (Nelson 2010; Hammill 2012). A great accomplishment of such political and ethical universalism was the Universal Declaration of Human Rights, which the United Nations adopted in 1948. However, the religious arguments between separatism and universalism reappeared in a new guise in the late-twentieth century, in international debates between the advocates of universal human rights and the defenders of cultural particularism (Donnelly 2007; Billet 2007). The problem of particularism versus universalism has haunted recent philosophers working in both Jewish and secular contexts (see the essays in Caputo and Alcoff 2007; also Hughes 2014).

What can we learn from the fact that, for more than two thousand years, biblical rhetoric of both religious separatism and of religious universalism has frequently been used to motivate and justify intolerance and violence? This history makes clear that setting traditions and their texts against each other can perpetuate great injustice, regardless of how subtle their ethical reasoning or how good their moral intentions may be. This conclusion is not an argument against modern efforts at inter-religious dialogue. Understanding between people of different religious traditions can only come about by 
learning from each other's practices and beliefs, and by interacting with each other personally. It is, however, an argument against the much older tendency, which is still prevalent today, of religious groups defining themselves by negative comparisons with other groups.

Daniel Boyarin concluded about the apostle Paul's universalism and ancient rabbinic particularism: "Both poles of this dialectic, the universalist thesis and the particularist antithesis, or, the particularist thesis and the universalist antithesis, present what seem to me to be both enormous ethical and political problems as well as enormous promise, each for reasons quite naturally directly opposite from the other" (Boyarin 1997, p. 201). That conclusion fits the entire history surveyed here, which raises the practical question of what to do about it. Some time ago, Rosemary Radford Ruether suggested that any and all universal claims should be "based on particularisms which accept their own distinctiveness and so leave room for the distinctiveness of others" and so "come to terms with [themselves] as a particularism among other particularisms, one language among other languages" (Ruether 1974, pp. 235, 237). Enacting Ruether's ideal would require religious communities to focus on themselves more than on comparisons with other groups. It recommends a stance of religious modesty that makes claims only for oneself and on behalf of one's own group. It recognizes the implicit imperialism of universalistic claims and the moral dangers that they pose.

I suggest that religious and cultural comparisons should lead us back to our own traditions to cultivate those parts that contribute to justice, wellbeing and peace, and to criticize and neutralize those parts that fuel injustice. Though cultural comparisons often fuel these efforts, this moral work can be done effectively only by those who, in one way or another, identify themselves and would likely be identified by others as belonging within the tradition, or in other words, by those who can reasonably claim the scriptures of the tradition as their own. ${ }^{2}$ To us falls the responsibility for describing the ideals of our traditions on their own terms, and for eliminating negative comparisons with other traditions that so easily turn into prejudice and oppression.

Funding: This research received no external funding.

Conflicts of Interest: The author declares no conflict of interest.

\section{References}

Angenendt, Arnold. 2009. Die Kreuzzüge. In Krieg und Christentum. Edited by Andreas Holzem. Paderborn: Ferdinand Schöningh, pp. 341-67.

Avalos, Hector. 2013. Slavery, Abolitionism, and the Ethics of Biblical Scholarship. Sheffield: Sheffield Phoenix Press. Ben-Sasson, Haim Hillel, ed. 1976. A History of the Jewish People. Cambridge: Harvard University Press.

Billet, Bret L. 2007. Introduction: Universal Human Rights versus Cultural Relativism. In Cultural Relativism in the Face of the West: The Plight of Women and Female Children. New York: Palgrave Macmillan.

Boyarin, Daniel. 1997. A Radical Jew: Paul and the Politics of Identity. Davis: University of California Press.

Caputo, John D., and Linda Martín Alcoff, eds. 2007. St. Paul among the Philosophers. Bloomington: Indiana University Press.

Carroll, James. 2001. Constantine's Sword: The Church and the Jews. Boston: Houghton Mifflin Harcourt.

Cave, Alfred A. 1988. Canaanites in a Promised Land: The American Indian and the Providential Theory of Empire. American Indian Quarterly 12: 277-97. [CrossRef]

Chrysostom, John. 2010. The Fathers of the Church. In Discourses against Judaizing Christians. Translated by Paul W. Harkins. Washington, DC: Catholic University of America Press, vol. 68.

Cole, Penny J. 1993. "O God, the heathen have come into your inheritance" (Ps 78.1): The Theme of Religious Pollution in Crusade Documents, 1099-1188. In Crusaders and Muslims in 12th c. Syria. Edited by M. Shatzmiller. Leiden: Brill, pp. 84-111.

Collins, John. 2017. The Invention of Judaism: Torah and Jewish Identity from Deuteronomy to Paul. Berkeley: University of California Press.

2 For one example of what a creative critique of traditional texts can look like, see Watts (2019). 
de Blasio, Guido, Diego Scalise, and Paolo Sestito. 2019. Universalism vs. Particularism: A Round Trip from Sociology to Economics. Review of Social Economy 77. [CrossRef]

de Pital, Marqués, and Miguel Salvá, eds. 1855. Carta del Doctor Pedro de Santander á S. M. fecha en Sevilla á 15 de julio de 1557. In Colección de Documentos Inéditos para la Historia de España. Madrid: La Viuda de Calero, vol. 26, pp. 240-65.

Dinnerstein, Leonard. 1994. Antisemitism in America. New York: Oxford University Press.

Donnelly, Jack. 2007. The Relative Universality of Human Rights. Human Rights Quarterly 29: 281-306. [CrossRef] Elliott, Mark W. 2012. Engaging Leviticus: Reading Leviticus Theologically with Its Past Interpreters. Eugene: Cascade. Frevel, Christian. 2019. Semper aliquid haeret! The Accusation of Fornication and of Sexualized Cults as a Means of Demarcation in the Hebrew Bible. In Religious Boundaries for Sex, Gender, and Corporality. Edited by Alexandra Cuffel, Anna Echavarria and Georgios T. Halkias. London: Routledge, pp. 11-21.

Goldenberg, David M. 2009. The Curse of Ham: Race and Slavery in Early Judaism, Christianity, and Islam. Princeton: Princeton University Press.

Hammill, Graham. 2012. The Mosaic Constitution: Political Theology and Imagination from Machiavelli to Milton. Chicago: Chicago University Press.

Haynes, Stephen R. 2002. Noah's Curse: The Biblical Justification of American Slavery. Oxford: Oxford University Press. Hidalgo, Jacqueline M. 2018. Latina/o/x Studies and Biblical Studies. Biblical Interpretation 3: 1-98.

Hughes, Aaron. 2014. Rethinking Jewish Philosophy: Beyond Particularism and Universalism. Oxford: Oxford University Press.

Levenson, Jon D. 1985. Is There a Counterpart in the Hebrew Bible to New Testament Antisemitism? Journal of Ecumenical Studies 22: 242-60.

Levy, Richard S., and Albert S. Lindemann. 2010. Antisemitism: A History. Oxford: Oxford University Press.

Mattox, Mickey L. 2008. Judaizers. In The New Westminster Dictionary of Church History: The Early, Medieval, and Reformation Eras. Louisville: Westminster John Knox, p. 365.

Milgrom, Jacob. 2000. Leviticus 17-22. Anchor Bible 3A. New York: Doubleday.

Murphy, Sean Eisen. 2007. Concern about Judaizing in Academic Treatises on the Law, c. 1130-c. 1230. Speculum 82: 560-94. [CrossRef]

Nasuti, Harry. 1986. Identity, Identification, and Imitation: The Narrative Hermeneutics of Biblical Law. Journal of Law and Religion 4: 9-23. [CrossRef]

Nelson, Eric. 2010. The Hebrew Republic: Jewish Sources and the Transformation of European Political Thought. Cambridge: Harvard University Press.

Newcomb, Steven T. 2008. Pagans in the Promised Land: Decoding the Doctrine of Christian Discovery. Golden: Fulcrum. Niditch, Susan. 1993. War in the Hebrew Bible: A Study in the Ethics of Violence. Oxford: Oxford University Press.

Olyan, Saul M. 2000. Rites and Rank: Hierarchy in Biblical Representations of Cult. Princeton: Princeton University Press.

Parkman, Francis. 1996. Pioneers of France in the New World. Lincoln: University of Nebraska Press.

Prior, Michael. 1997. The Bible and Colonialism: A Moral Critique. Sheffield: Sheffield Academic Press.

Richardson, Peter, and Stephen Pihlaja. 2018. Killing in the Name: Contemporary Evangelical Christian Interpretations of the Jericho Massacre in the Context of Anti-Immigration and Anti-Muslim Trends. Postscripts 9: 27-49. [CrossRef]

Ruether, Rosemary Radford. 1974. Faith and Fratricide: The Theological Roots of Anti-Semitism. New York: Seabury Press.

Sanders, Seth L. 2009. The Invention of Hebrew. Urbana: University of Illinois.

Schäfer, Peter. 1997. Judeophobia: Attitudes towards the Jews in the Ancient World. Cambridge: Harvard University Press.

Schott, Jeremy M. 2013. Christianity, Empire, and the Making of Religion in Late Antiquity. Philadelphia: University of Pennsylvania Press.

Simkovich, Malka Z. 2017. The Making of Jewish Universalism: From Exile to Alexandria. Lanham: Lexington Books. Stark, Rodney. 2004. For the Glory of God: How Monotheism Led to Reformations, Science, Witch-Hunts, and the End of Slavery. Princeton: Princeton University Press.

Staubli, Thomas. 2011. Antikanaanismus: Ein biblisches Reinheitskonzept mit globalen Folgen. In Reinheit. Edited by Peter Burschel and Christoph Marx. Vienna: Böhlau Verlag, pp. 349-87.

Stevens, Paul. 1993. "Leviticus Thinking" and the Rhetoric of Early Modern Colonialism. Criticism 35: 441-61. 
Sugirtharajah, Rasiah S. 2005. The Bible and Empire: Postcolonial Explorations. Cambridge: Cambridge University Press.

Suttampillai, Arumai Nayakam. 1890. A Brief Sketch of the Hindu Christian Dogmas. Palamcottah: Shanmuga Vilasam Press.

Warrior, Robert Allen. 1989. Canaanites, Cowboys, and Indians: Deliverance, Conquest, and Liberation Theology Today. Christianity and Crisis 49: 21-6.

Watts, James W. 2017. Understanding the Pentateuch as a Scripture. Oxford: Wiley Blackwell.

Watts, James W. 2019. Drawing Lines: A Suggestion for Addressing the Moral Problem of Reproducing Immoral Biblical Texts in Commentaries and Bibles. In Writing a Commentary on Leviticus: Hermeneutics—Methodology_-Themes. Edited by Thomas Hieke and Christian A. Eberhart. FRLANT 276. Göttingen: Vandenhoeck \& Ruprecht, pp. 235-52.

Wilkens, David E. 2014. Deconstructing the Doctrine of Discovery. Indian Country Today, October 24.

(C) 2020 by the author. Licensee MDPI, Basel, Switzerland. This article is an open access article distributed under the terms and conditions of the Creative Commons Attribution (CC BY) license (http://creativecommons.org/licenses/by/4.0/). 